\begin{tabular}{|l|l|l|l|l|}
\hline $\begin{array}{l}\text { Cuadernos de Investigación Geográfica } \\
\text { Geographical Research Letters }\end{array}$ & 2019 & N$^{\circ} 45(1)$ & pp. 219-244 & eISSN 1697-9540 \\
\hline
\end{tabular}

\title{
HUMAN IMPACT IN THE TATRA MOUNTAINS
}

\section{Z. RĄCZKOWSKA}

\begin{abstract}
Department of Environmental Research, Institute of Geography and Spatial Organization, Polish Academy of Sciences, 31-018 Kraków, Św. Jana Str. 22, Poland.
\end{abstract}

\begin{abstract}
Human activity is one of the three main drivers of environmental changes in the mountains. Its influence on mountain natural environment is characterized by great spatiotemporal diversity. In the Tatras human impact started in the $12^{\text {th }}-13^{\text {th }}$ centuries and was related to mining and animal grazing, followed by metallurgy in the $18^{\text {th }}$ century. These activities developed in the $15^{\text {th }}-16^{\text {th }}$ and with the climax in the $18^{\text {th }}-19^{\text {th }}$, except for the animal grazing which continued till the 1960s-1970s. Since the second half of the $19^{\text {th }}$ century tourism developed intensively. More than 3 million people per year visit the Polish part of the Tatras nowadays.
\end{abstract}

Human activities, prior to tourism, were accompanied by a strong forest and dwarf pine shrubs extraction. They affected mainly relief and vegetation cover. Erosion in the slopes was triggered or intensified after deterioration of vegetation cover by grazing. Anthropogenic landforms like pits, mine roads, mine channels are still recognizable in landscape. Lowering of the upper forest and dwarf pine limits and changing of a natural structure of the forest into a monoculture are among the main influences on vegetation. Indirect effects of the changed forest structure are problems with bark beetles and windthrows. The later have been strongly affecting slope morphodynamics. Tourism-related impact manifest in gradual anthropogenic erosion along hiking trails. It is the major type of human impact $n$ the Tatras now. The historical human impact until the 1960s-1970s was indeed spatial in nature. Currently, it is of a linear character or point-focused, and is relatively constant regarding particular locations.

\section{El impacto humano en los Montes Tatra}

RESUMEN. La actividad humana es uno de los tres principales agentes de los cambios ambientales en las montañas. Su influencia en el ambiente natural montano se caracteriza por una gran diversidad espacio-temporal. El impacto humano en los Tatras comenzó en los siglos XII-XIII y se relacionó con la minería y el pastoreo, seguidos por la metalurgia en el siglo XVIII. Estas actividades se desarrollaron durante los siglos XV-XVI, alcanzando su climax en los siglos XVIII-XIX, excepto en el caso del pastoreo, que continuó hasta las décadas de 
1960-1970. Desde la segunda mitad del siglo XIX el turismo se desarrolló intensivamente. Más de tres millones de personas al año visitan la parte polaca de los Tatra actualmente.

Las actividades humanas anteriores al turismo estuvieron acompañadas por una fuerte explotación forestal, que afectó principalmente al relieve y a la cubierta vegetal. La erosión en las laderas se inició o intensificó tras el deterioro de la vegetación por el pastoreo. Formas de origen antropogénico como canteras, caminos mineros y canales mineros se reconocen todavía en el paisaje. El descenso altitudinal del límite superior del bosque y de los pinos enanos y los cambios en la estructura natural del bosque están entre las influencias sobre la vegetación. Los efectos indirectos de los cambios de estructura forestal son problemas relacionados con el escarabajo de la corteza y las caídas de árboles por el viento. Estas últimas han afectado intensamente a la morfodinámica de laderas. Los impactos relacionados con el turismo se manifiestan en erosión antropogénica a lo largo de los caminos de monta$\tilde{n} a$, que es el mayor tipo de impacto actual en los Tatra. El impacto humano histórico en las décadas de 1960 y 1970 fue por ello de naturaleza espacial. Actualmente presenta un carácter lineal o muy local, y es relativamente constante en determinados lugares.

Key words: Human impact, Tatra Mountains, mining, metallurgy, pasturage, deforestation, tourism, landform, vegetation cover, water resources.

Palabras clave: Impacto humano, Montes Tatra, minería, metalurgia, pastoreo, deforestación, turismo, formas de relieve, cubierta vegetal, recursos hídricos.

*Corresponding author: Zofia Rączkowska, Department of Environmental Research, Institute of Geography and Spatial Organization, Polish Academy of Sciences, 31-018 Kraków, Św. Jana Str. 22, Poland. E-mail address: raczk@zg.pan.krakow.pl.

\section{Introduction}

Mountains are characterized by greater geodiversity than most landscapes (Barsch and Caine, 1984). Three drivers of environmental changes in the mountains are relief (Tucker and Slingerland, 1994), hydroclimate and runoff (Vandenberghe, 2002), and human activity (Coulthard and Macklin, 2001). Mountain geosystems are not exceptionally fragile but show greater vulnerability to disturbance than many other landscapes (Beniston 2000). Human activity resulting in a specific land use as well as land cover patterns that often go across geoecological zones generally accelerated landscape disturbance (Slaymaker and Embelton-Hamman, 2009). 
Mountain areas in Europe are being under impact of diverse human activities since thousands years. Paleostudies highlight the occurrence of human activities there like grazing, agriculture, mining, industry and others (eg. Galop and Jalut 1994; Valsecchi et al., 2010; Py et al., 2014). The type and intensity of human influence is characterized by large spatio-temporal variability. Agricultural land abandonment is observed in the European mountain areas since the last 200 years, with significant intensification since the fifties of the $20^{\text {th }}$ century (MacDonald et al., 2000; Galop et al., 2013, Lasanta et al., 2017). Recently it is accompanied by abandonment of grazing areas (Bauer et al., 2006; Galop et al., 2013). Urbanization and increase in population is generally observed in the Alps (Batzing et al., 1996), but in their remote areas as well as in other mountains (e.g. Pyrenees) population is declining, with some areas in danger of becoming completely abandoned (Batzing et al., 1996). Lastly, the impact of increasing winter skiing is of major importance (Rixen and Ronaldo, 2013).

Human activities have contributed, in general, to the disturbance of the original landscape and its morphodynamics (García-Ruiz and Valero-Garcés, 1998; Latocha, 2009; Py et al., 2014) as well as of mountain vegetation by changes in timberline or species distribution (Valsecchi et al., 2010; Schwörer et al., 2014). The recent decline in farming and grazing caused extent of forest and treeline expansion toward higher altitudes (Leonelli et al., 2013; Bebi et al., 2017).

However, the high-mountain environment of the Tatras is regarded as being only slightly changed by humans. Human interference in the natural environment of the Tatra Mountains has occurred since medieval times with spatially and temporally differentiated intensity as it appears from historical materials and is documented by sediments in glacial lakes in cirques and over-deepened basins (Libelt, 1988; Kaszowski et al., 1988; Kłapyta and Kołaczek, 2009; Kłapyta, 2012). This human impact has caused intentional and unintentional changes in the natural environment, especially in the landscape, in each altitudinal belt and with variable intensity.

The aim of this paper is to examine the human impact on the natural environment of the Tatras. The human activities influencing the natural environment will be considered with a special attention paid to their spatial extent and temporal variability. The changes in most affected elements of the natural environment will be discussed based on results of the studies regarding particular elements of natural environment.

\section{Study area}

The Tatras (area of $785 \mathrm{~km}^{2}$ and length of $53 \mathrm{~km}$ ) are the highest mountain range in the whole Carpathian arc, elevated up to $2655 \mathrm{~m}$ a.s.l. (Gerlachovský štít peak). Approximately $4 / 5$ of the area belongs to Slovakia, and the remainder to Poland. This region of diverse geology and relief is divided into four physico-geographical mesoregions: the High Tatras, the Western Tatras, the Belianske Tatras and the Reglowe Tatras (Radwańska-Paryska and Paryski, 1995; Balon et al., 2015) (Figs. 1 and 2). 


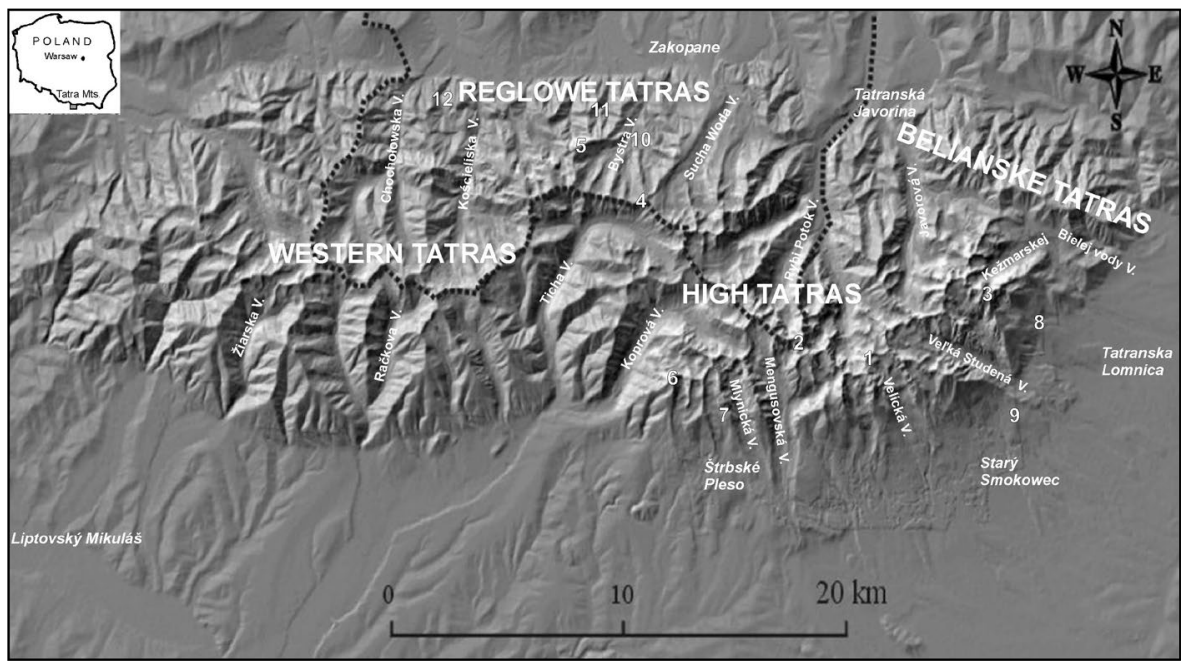

Figure 1. Location of the study area. Black dots: state boundary between Poland and Slovakia. 1: the Gerlachovský štít Mt.; 2: the Rysy Mt.; 3: the Lomnický štit Mt.; 4: the Kasprowy Wierch Mt.; 5: the Giewont Mt.; 6; the Kriván Mt.; 7 : the Predné Solisko Mt.; 8: the Skalnaté pleso lake; 9: the Hrebienok; 10: Kuźnice hamlet and Dolina Jaworzynki Valley; 11: Dolina Białego Valley; 12: Dolina Lejowa Valley.

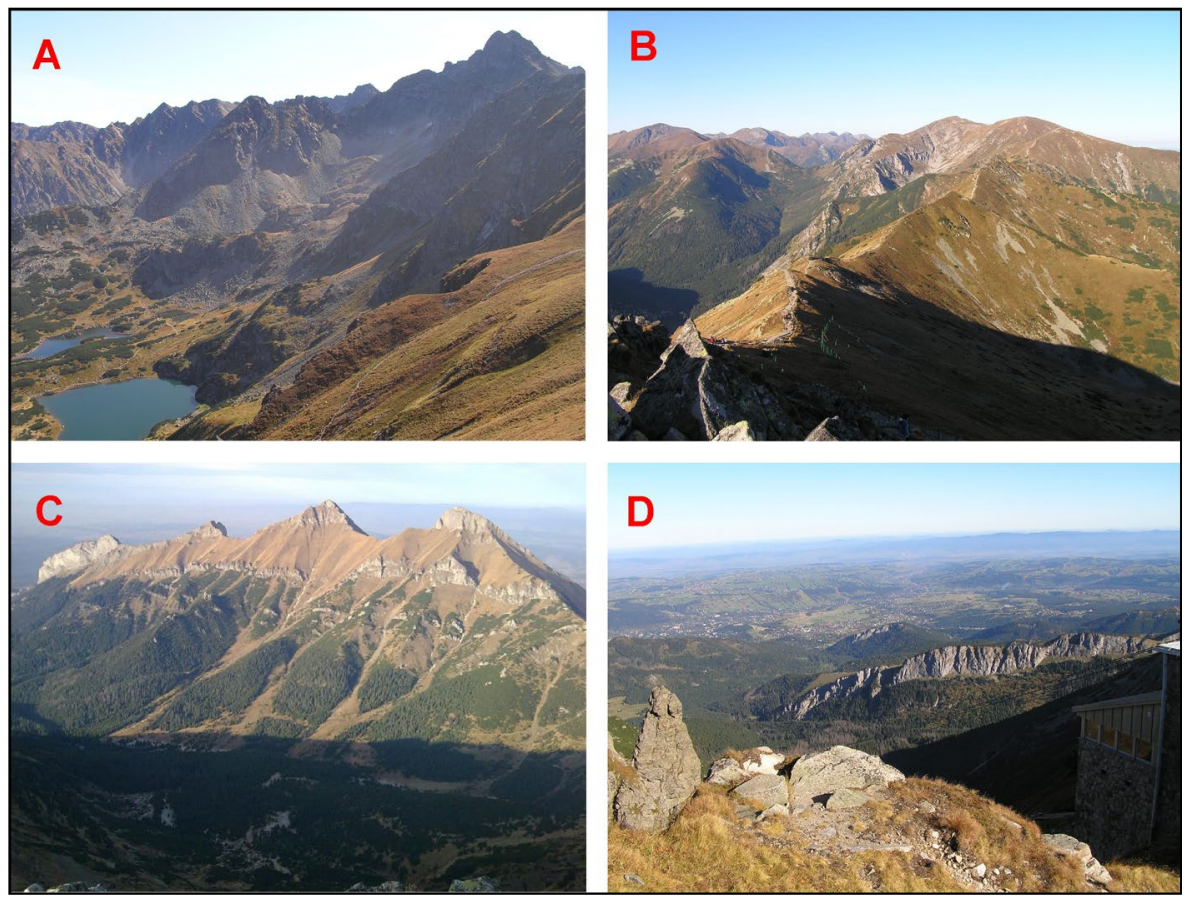

Figure 2. Landscape of the Tatra Mts. A: the High Tatras; B: the Western Tatras; C: the Belanske Tatras; D: the Reglowe Tatras. 
The Tatras are composed of a crystalline core formed of intrusive Carboniferous granitoids of the High Tatras and metamorphic rocks (Paleozoic rocks: gneiss, amphibolite, metamorphic shale) occurring mainly in the Western Tatras. The core is rimmed from the north by allochthonous High Tatric Nappe and Sub-Tatric Nappes, consisting of quartzite, dolomite, limestone, marls, shales, and sandstone of the TriassicMiddle Cretaceous age (Piotrowska et al., 2015).

The Tatras are characterized by alpine relief formed during the Pleistocene glaciations (Lukniš, 1973; Klimaszewski, 1988; Rączkowski et al., 2015). Thus, in the High Tatras a system of glacial cirques and glacial troughs was formed, both with very steep and rocky slopes, deeply incised by couloirs with large talus cones at their outlets (Fig. 2a). In the Western Tatras (Fig. 2b) only the upper sections of the valleys were glaciated. The bottoms of the cirques are not over-deepened, the rocky slopes and rock walls are shorter than in the High Tatras and often replaced by debris-mantled slopes. The Belianske Tatras (Fig. 2c) have both glacial and karst relief. The fluvio-denudational relief that is indeed typical of medium-high mountains characterizes the Reglowe Tatras (Fig. 2d). Cuesta-like ridges are characteristic features both in the Belianske and Reglowe Tatras (Lukniš, 1972; Klimaszewski, 1988; Rączkowski et al., 2015).

The mean annual air temperature (MAAT) at the foothills of the northern Tatras is $6^{\circ} \mathrm{C}$. At the highest summits, MAAT is $-2^{\circ} \mathrm{C}$ (Żmudzka et al., 2015). The mean total precipitation ranges from approximately $1100 \mathrm{~mm}$ at the northern foothills to more than $2000 \mathrm{~mm}$ in higher parts (Ustrnul et al., 2015), and the number of days with seasonal snow cover ranges from about 100 to over 220, respectively (Ustrnul et al., 2015).

The upper timberline is at $1520 \mathrm{~m}$ a.s.l., the subalpine zone, which is formed by dwarf pine (Pinus mugo) shrub, reaches to $1850 \mathrm{~m}$ a.s.l., the zone of alpine meadows - up to $2300 \mathrm{~m}$ a.s.1, and the subnival zone is above. Altitude between 1520 and 1250 is occupied by the upper montane forest zone with coniferous forest, mostly composed by spruce (Picea abies). Below, the lower montane forest zone, which is formed by deciduous forest with predominating beech (Fagus sylvatica) and fir (Abies alba), descends to 700 m a.s.l. (Piękoś-Mirkowa and Mirek, 1996) but actually is dominated by monocultures of spruce.

The area is legally protected as Polish and Slovak national parks and as an international biosphere reserve (UNESCO). The Tatra National Park (TANAP) in Slovakia was founded in 1949 and in Poland (TPN) in 1954. Together, they cover the whole area of the Tatras. A few kilometres wide buffer protection zone extends outward, along their borders. Since 1993 the Tatras have become a Man and Biosphere Reserve, while some parts are under Natura 2000 protection.

\section{Outline of history of human activity in the Tatras}

Human activities in the Tatras in the past were related to mining, grazing, wood and oil extraction, and rubber forest management. After the foundation of TANAP and TPN, according to the principles of their operation, all human activities, except tourism, were gradually stopped. Currently, human activity is limited to tourism. 
Tourists are allowed to go only along designated hiking trails. In the forest zone of the TANAP, some cultivated forests are permitted. The Tatras are uninhabited, only mountains lodges are there. Small towns and resorts exist along their border, among which Zakopane is the largest (about 30,000 inhabitants). However, Mirek (1996) distinguishes nearly 50 different forms of anthropopression there, among which, in addition to long-range impacts i.e., atmospheric pollution, the most important is tourism, sport and recreation pressure.

\subsection{Mining and metallurgy}

Mining started on the Slovak/southern side of the Tatras in the $12^{\text {th }}$ century and on the Polish/northern side of the Tatras in the $13^{\text {th }}$ century. Although the development of mining was already intensive in the $15^{\text {th }}$ and $16^{\text {th }}$ centuries, when 1494 mines operated in the Polish part of the Tatras, yet the $17^{\text {th }}$ and $18^{\text {th }}$ centuries are the periods of mining climax, especially on the Polish side. Silver, cooper and iron ores were extracted at the beginning, while gold to a lesser degree. Later on, iron ore extraction dominated, especially in the $18^{\text {th }}$ century. The mining activity concentrated in the Chochołowska Valley, the Kościeliska Valley, the Jaworzynka Valley, the Kriván Mt., the Velická Valley, the Kežmarskej Bielej vody Valley (Fig. 3). The pits and adits were located on slopes even near the ridges, and the ore was transported down along special roads cut into the slopes (hawiarska droga i.e. so called miners' routes) (Häufler, 1955; Midriak, 1972; Szafarski, 1972; Radwańska-Paryska and Paryski, 1995). Prospecting for uranium in the 1950s, documented by relict adits in the Dolina Białego Valley, was the last mining activity in the area.

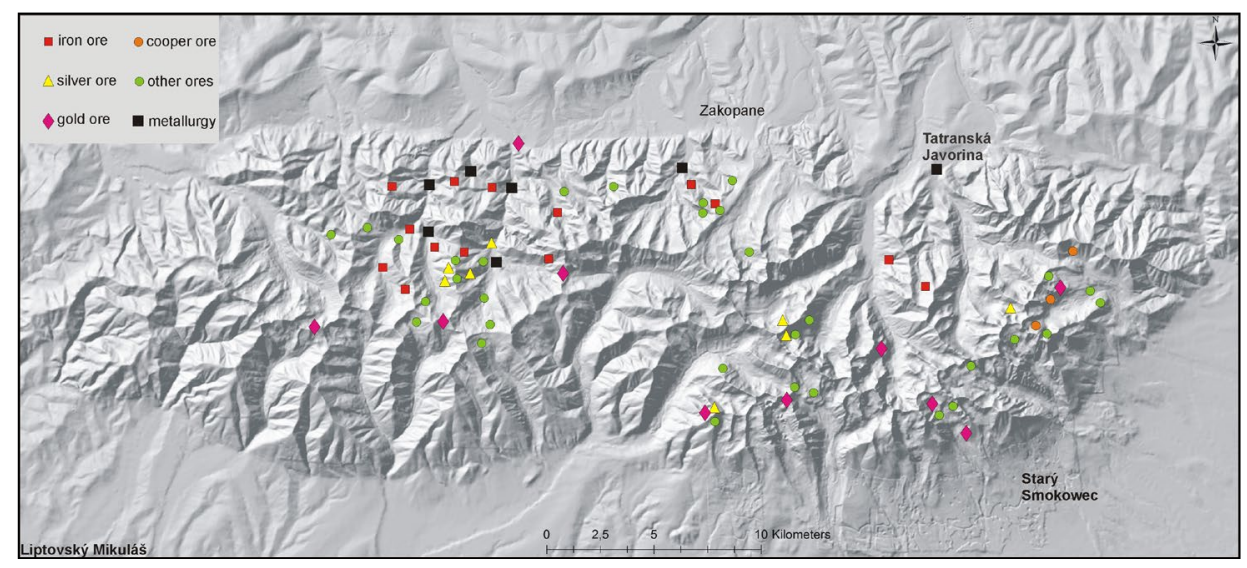

Figure 3. Mining and metallurgy in the Tatras.

Since the beginning of the $18^{\text {th }}$ century metallurgy developed. The smelting centre was in Tatranská Javorina village, and the ironworks in the Bystra Valley (Kuźnice), the Kościeliska Valley (the Hala Ornak, the Stare Kościeliska), the Chochołowska Valley (the Polana Huciska, the Starorobociańska Dolina), the Lejowa Valley. The smelting 
activity finished in 1880 (Liberak, 1927; Häufler, 1955; Jost, 1962; Szafarski, 1972; Jost and Paulo, 1985).

After the break down of metallurgy and mining, paper mills developed in the former centre of iron works in the Kuźnice hamlet. For this reason 3 big saw mills exist in the village of Zakopane at the Tatras margin (Jost and Paulo, 1985; Jost, 1991).

In relation to this activity, lime kilns were active, what stimulated rock extraction and stone-pits development not far from Kuźnice and the Dolina Kościeliska industry centres (Jost and Paulo, 1985).

\subsection{Wood exploitation and essential oil extraction}

When metallurgy was developing, charcoal was needed as well as wood for casing the mining adits and pits. Around $16000 \mathrm{~m}^{3}$ of wood were used per year for the latter, while ca. $37 \mathrm{~m}^{3}$ were used for getting 1 ton of pig iron. For this reason, the forests in both the marginal zone and inside the mountains were cut down. Natural forests have survived only in hard-to-reach areas (Zwoliński, 1984; Myczkowski et al., 1985). Deforestation took place also in the Tatras foreland (Zwoliński, 1984).

The strongest tree cutting down in the montane forest zone on the northern side of the Tatra Mountains took place in the $19^{\text {th }}$ century, until 1889, when Count W. Zamojski bought the majority of the forests. Acquiring wood for steelworks and for construction purposes caused the destruction and changes in the forest stand structure, introduction of alien spruce species to inappropriate habitats (Fabijanowski, 1962; Dziewolski and Skawiński, 1988; Mirek, 1996). In fact, a monoculture spruce forest developed instead of a mixed forest of the lower montane zone and a native spruce forest of the upper montane zone (Jost, 1991; Mirek, 1996). Deforestation was also related to pasturage, which also influenced the forest structure due to grazing of forest undergrowth. Moreover, the forest was strongly infected by bark beetle since the World War I, what was caused by negligence in forest management (Goetel, 1962).

A special type of human activity concentrated on southern side of the Tatras was the production of essential oil from dwarf pine by distillation. It was run mainly from 1897 to 1904 together with the exploitation of dwarf pine bushes in the Kežmarskej Bielej vody Valley (Gašpar, 2002). The oil mill exists there near Bele pleso lake (Janoška, 1923). As a result, entire slopes were stripped of dwarf pine shrubs, as it is evidenced by Pinus mugo roots fragments found in the place where the shrubs are now absent (Midriak, 1972). Effects were visible in the $20^{\text {th }}$ century for a long time (Goetel, 1962; Boltižiar, 2007).

\subsection{Grazing}

The first pasturing activity in the Tatras dates back to the $12^{\text {th }}$ century and continued till the $14^{\text {th }}$ century, and was related to the German colonization in the 
surrounding area. Extensive grazing developed at the turn of the $14^{\text {th }} / 15^{\text {th }}$ centuries, when Wallachian shepherds arrived in the region and the climax of pasturing activity took place in the $16^{\text {th }}$ and $17^{\text {th }}$ centuries (Holub-Pacewiczowa, 1931; Chaloupecký, 1957). The grazing land covered the area above the upper timberline up to $2500 \mathrm{~m}$ a.s.l., as well as forest glades and logging sites in the forest zone. Sheep dominated among grazing animals, although cows, horses, goats and pigs were also raised. Cattle were grazed mainly on the southern side of the Tatras. The highest number of grazing animals were in the Polish part of the Tatras and in the Belianske Tatras (Holub-Pacewiczowa, 1931; Fabijanowski, 1962; Harvan, 1965; Podolák, 1967; Fabijanowski and Dziewolski, 1996). The greatest development of pastoralism falls on the $19^{\text {th }}$ century and the first half of the $20^{\text {th }}$ century (Kolowca, 1955). The maximum intensity of grazing was in the period of 1939-1945, when 35,000 sheep per year grazed in the Tatras (Radwańska-Paryska, 1963) and in the period of 19421947 when 13,000-26,000 sheep per year grazed in the Polish Tatras (Śmiałowska, 1962). Grazing was accompanied by the existence of shepherds' shelters and huts, located in great number even in remote areas at high altitude in the mountains or near cheese-making workshops in the valley bottoms (Midriak, 1972; Chmiel, 1996). The shepherds' huts were located up to 1500-1600 m a.s.l. (Haufler, 1955; Midriak, 1983). Later, the number of grazed animals decreased to around 6,000 per year in the 1960s (Śmiałowska, 1962) and, in the years 1960-1972, pastoralism was withdrawn from the Tatras in the interest of nature conservation. Grazing continued only in some clearings until 1978. In 1981, the limited, so called cultural, pasturage of sheep, in number of about 1000 heads, was reintroduced in few glades in the lower forest montane zone (Chmiel, 1996). Since the time of pasturage ban, some abandoned pastureland has undergone natural succession, while some have been reforested as part of a major government afforestation program in Poland.

\subsection{Tourism types and dynamics}

The interest in tourism in the Tatras dates back to the second half of the $16^{\text {th }}$ century, and since the $17^{\text {th }}$ century climbing the peaks of the Tatras became an appealing venture. In the $18^{\text {th }}$ century and the first half of the $19^{\text {th }}$ century tourism was relatively vivid, and it intensified when the first mountain refuge was built near the Morskie Oko lake in the Dolina Rybiego Potoku Valley in 1836 on the northern side, and then another shelter (Rainerova chata) in the Vel'ká Studená dolina valley in 1863 on southern side of the Tatras (Radwańska-Paryska and Paryski, 1995). Development of tourism was related to the Tatra Association foundation in 1873, which improved accommodation and trails availability in the Tatras. Also expansion of tourist resorts at the base of the Tatras (Zakopane, Starý Smokovec, Štrbské Pleso, etc.) and accessibility to these places by newly constructed railway roads in a half of the $19^{\text {th }}$ century significantly influenced tourism intensity in the Tatras. It is expressed by a growing number of people visiting the Polish part of the Tatras from around 100 in 1870 to more than 3 millions per year nowadays. The number of tourist reached 8000 in 1900,150000 in 1948, 1 million in 1960 and more than 2 million in 1970 (Mirek, 1996; Fidelus et al., 2017). 
Tourist traffic is not evenly distributed in the area (Fig. 4). According to simultaneous monitoring of visitors in 2004, in the entire Tatras (TANAP and TPN) almost 16000 tourists on average entered daily the Tatra valleys in TANAP (Sturcel, 2006), while 27805 entered valleys in the TPN (Czubernat and Marchlewski, 2005). On the Slovak side of the Tatra mountains there are 4 places where the intensity of tourist traffic exceeds 2000 persons/day: the Predné Solisko Mt. in the Mlynická Valley (cable car and chair lifts), the Popradské pleso lake region in the Mengusovská Valley, the Hrebienok area (cog railway and chair lifts) and the Lomnický štit Mt. and the Skalnaté pleso lake (chair lift and cable car) (Švajda and Šturcel, 2005). On the Polish part these are: the Dolina Rybiego Potoku valley and the Morskie Oko lake ( $>5000$ persons/day); the Dolina Kościeliska ( $>2000$ persons/day); the Dolina Białego valley, the Chochołowska Valley, the Jaworzynka Valley, the Bystra Dolina valley and the Giewont Mt., (>1000 persons/day) and the Kasprowy Wierch peak (cable car transported $>500000$ persons/year and chair lifts) (Fidelus et al., 2017). From the places mentioned above, cable lifts (gondola cars) allow the access to higher parts of the mountains, while the remaining parts of the alpine zone are characterized by a notably less intensive tourist traffic. Tourist traffic concentrates in summer, from June to September, with the maximum in August (Švajda and Šturcel, 2005; Fidelus et al., 2017). More than $70 \%$ of tourists, from among those entering the valleys, reach only mountain huts located usually in the bottom of valley heads (Fidelus et al., 2017). The current hiking routes are largely past pastoral trails and roads (Mirek, 1996).

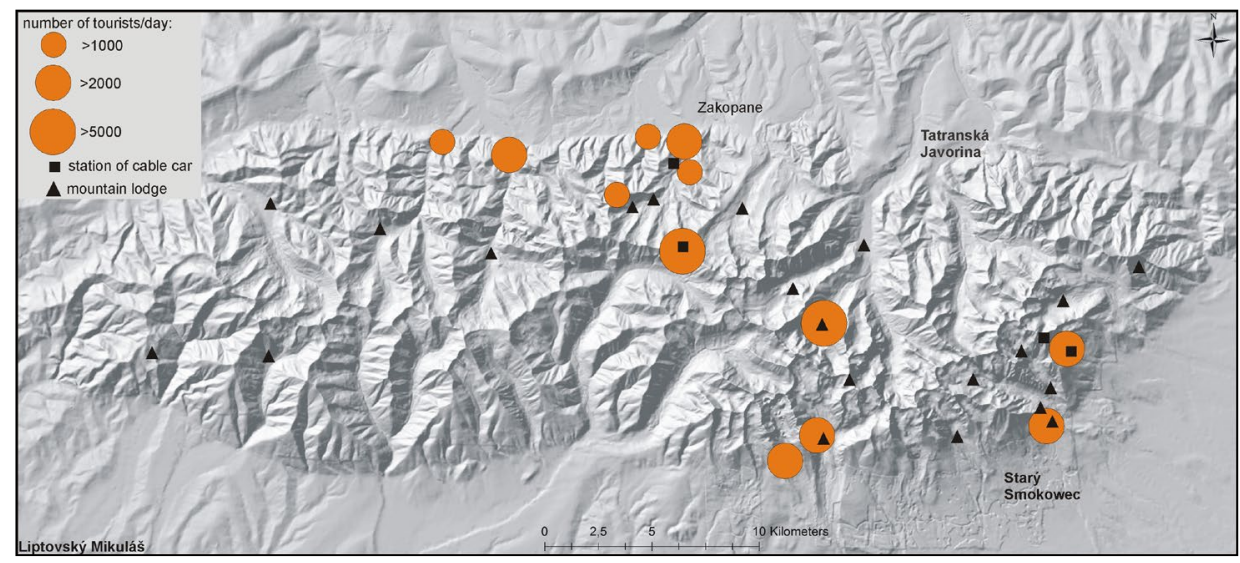

Figure 4. Tourism in the Tatras. The intensity of tourist traffic. Location of the station of cable car and mountain lodges.

Tourism takes different forms in the Tatras. The main type is hiking along hundreds kilometres of hiking paths $(275 \mathrm{~km}$ in TPN), leading from the bottoms of the valleys, where they usually have the form of unpaved roads, up to the ridges. Since a half of the $20^{\text {th }}$ century a specific variety of tourism is the sporting penetration of the karst caves. Two hundred caves among 650 on the Polish part of the Tatras were visited by 50000 
persons in the period of 1982-1988 (Siarzewski, 1996). The other type of tourist activity is climbing, with drytooling and bouldering being the most popular actually (Jodłowski, 2015). Also cycling is allowed on roads in the bottoms of few main valleys, both on the Polish and the Slovak parts of the Tatras. Skiing dates back to the period of 1891-1894. Since that time, downhill skiing became popular in the entire mountain range. In the 1930s infrastructure for skiers started to be constructed, among them cable cars on the main ridge of the Tatras at the Lomnický štit Mt. and the Kasprowy Wierch Mt. (Fig. 4). Nowadays, skiing concentrates in few places near chair lifts and cable cars (Skawiński and Krzan, 1996). A rapid increase in popularity of ski-touring has been noted in recent years.

\subsection{Temporal variability of human impact}

The intensity of various types of human activity in the Tatras and their surroundings changed trough time (Fig. 5). Mining and grazing were the main types affecting the environment of the Tatras till the mid-20 $0^{\text {th }}$ century. Later the tourism, both summer walking and winter skiing became the main activities, unfortunately becoming also real threats to the natural environment there. The influence of climbing on the environment is negligible. The tourism impact is expressed by a growing number of tourists and by the development of infrastructures. Apparently, human influence is well evident in the Belianske Tatras, less in the Western Tatras and the least in the High Tatras (Midriak, 1983).

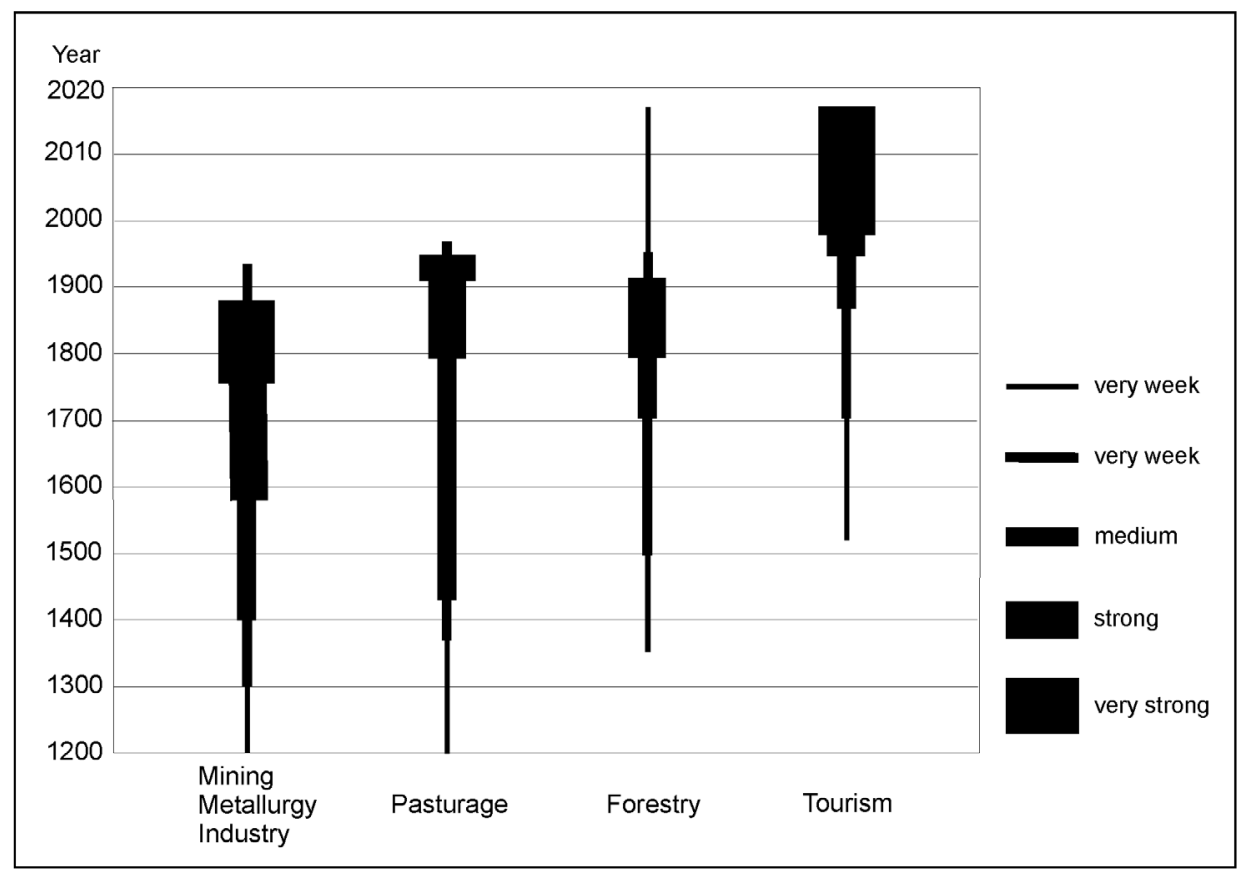

Figure 5. Temporal variability of human activities in the Tatras. 


\subsection{Climate changes in the period of human presence in the Tatras}

Simultaneously with the increasing human activity the climate changes were going on, i.e. the entry of humans to the Tatras was parallel to the climate deterioration during the Little Ice Age (LIA). The latter resulted in the increased activity of slope processes, especially debris flows, avalanches and floods (Kotarba, 2004; Gądek et al., 2016; Gądek et al., 2017). It is assumed that the LIA lasted until the beginning of the $20^{\text {th }}$ century (Kotarba, 2004). For humans the changes were very unfavourable because they were accompanied by a shortened vegetation period and crop yield deficiency that fostered the spread of famine and various epidemics (Kędzia and Kotarba, 2018). Unlike in the LIA, there is an actual tendency for air temperature to rise. The climate warming has been proved, so that in the last hundred years mean annual temperature increased about $1{ }^{\circ} \mathrm{C}$ (Żmudzka et al., 2015).

\section{Human impact}

\subsection{Influence of mining, iron metallurgy and paper mills}

The most significant influence of mining and other industry on the nature of the Tatras took place in the $18^{\text {th }}$ and the first half of the $19^{\text {th }}$ centuries (Fig. 5). These activities resulted in: construction of a road for ore transportation along the main valley bottom, urbanization of the mountains margin, and deforestation or degradation of forest (Fabijanowski, 1962; Fabijanowski and Dziewolski, 1996; Mirek, 1996). On the Tatra slopes many adits, pits and mine piles emerged. A system of mine roads was formed across the slopes for transporting the ore to the valley bottom. Even small workshops smelting non-ferrous metal operated in valley heads not only near mouths of the valleys at the mountains margin. Special channels were formed for water transport to foundry furnaces (Jost, 1962, 1991). The remnants of mining and smelting activities are still present in the relief as anthropogenic landforms. Among them mine roads are most significant, besides channels formerly supplying water to mines. They are still clearly visible in the Tatra landscape. In addition, pits of limestone quarries are anthropogenic landforms. Along the northern border of the Tatras the former mine roads that connected smelting centres in the Dolina Kościeliska and the Dolina Chochołowska valleys with Kuźnice in the Bystra Valley, are used now as popular hiking path. The activity mentioned above caused substantial changes in the vegetation cover. These changes were intentional like in the case of deforestation or unintentional like in the case of influence of deforestation on soils and morphodynamics of slopes. The problem will be discussed in a separate chapter.

\subsection{Influence of grazing on vegetation cover}

The influence of grazing seems to be stronger than that of mining and metallurgy as pasturing spatially covers almost the whole Tatras, from the valley bottoms to the divides. Pasturing had the influence both on the change in the structure of the zonal types of vegetation and the spatial extent of main types of vegetation (i.e. alpine meadows, 
dwarf pines, shrubs and forests) and on the conditions for morphogenetic process that, in turn, influenced slope morphodynamics. Moreover, anthropogenic landforms are still common elements of the Tatra's landscape.

Initially, the influence of grazing was marked by the synanthropic flora (Radwańska-Paryska, 1963) and small changes in vegetation due to grazing and manuring, but there was no destruction of the vegetation cover that was observed subsequently (Radwańska-Paryska, 1959). Over the years, however, the pressure of pastoralism increased rapidly, and at the beginning of the $17^{\text {th }}$ century, the problem of excessive use of the Tatra forests appeared. As a result of all human activities, $10 \%$ of vascular plants in the TPN (100 species) have been unintentionally or intentionally introduced (Mirek, 1996).

In the alpine grasslands zone, the impact of grazing manifests in reducing the density of alpine swards and replacing natural grassland communities by the secondary ones. In places with the entirely destroyed vegetation cover, an initial phase of cryptogamic plant communities can be observed on screes (Balcerkiewicz, 1984; Mirek, 1996; Rączkowska and Kozłowska, 2002).

Pasturage significantly affected to deterioration in the montane forest and subalpine dwarf pine zones (Fig. 6). In the first case, destructions were related to forest fires and mechanical damage of trees or tree roots, while in the second case, plucking out and fires damaged mainly the Pinus mugo shrubs (Haufler, 1955; Fabijanowski, 1962; Midriak, 1972; Fabijanowski and Dziewolski, 1996). The area covered in the past by dwarf pine had been stripped of it by grazing in 60$90 \%$ in the Western Tatras (Haufler, 1955; Midriak, 1983). In areas where dwarf pine shrubs were removed, the development of subalpine grassland communities followed the grazing. In the subalpine zone, such patches of grasslands over crystalline bedrock most often consist of communities with Deschampsia flexuosa and Festuca picta or post-grazing subalpine form of alpine sward (Oreochloo distichae-Juncetum trifidi). In the transition zone between the subalpine and the alpine zones this post-grazing subalpine plant cover often occurs in a complex with patches of dwarf shrubs (Vaccinium myrtillus). In the alpine zone occurrence of some subassociations like Oreochloo distichae-Juncetum trifidi caricetosum sempervirentis could be related to grazing (Rączkowska and Kozłowska, 2002; Kozłowska, 2008).

Lowering of the upper limit of the subalpine dwarf pine and montane forest zones was one of the most significant effects of grazing (Figs. 6 and 7, b; Sokołowski, 1928; Plesník, 1971, 1973; Midriak, 1983; Boltižiar, 2007; Guzik, 2008; Jodłowski, 2010). Lowering of the upper limit of the forest zone occurred on $70 \%$ of its length in the Western Tatras and 50\% in the High Tatras (PiękośMirkowa, 1986). The upper limit of the forest has clearly went down: by 100$150 \mathrm{~m}$ in the Western Tatras (Sokołowski, 1928), 190-220 meters (Plesník, 1971, 1973) or 130 meters (Midriak, 1983) in the High Tatras, and by 200 meters in the Belianske Tatras (Midriak, 1983). 


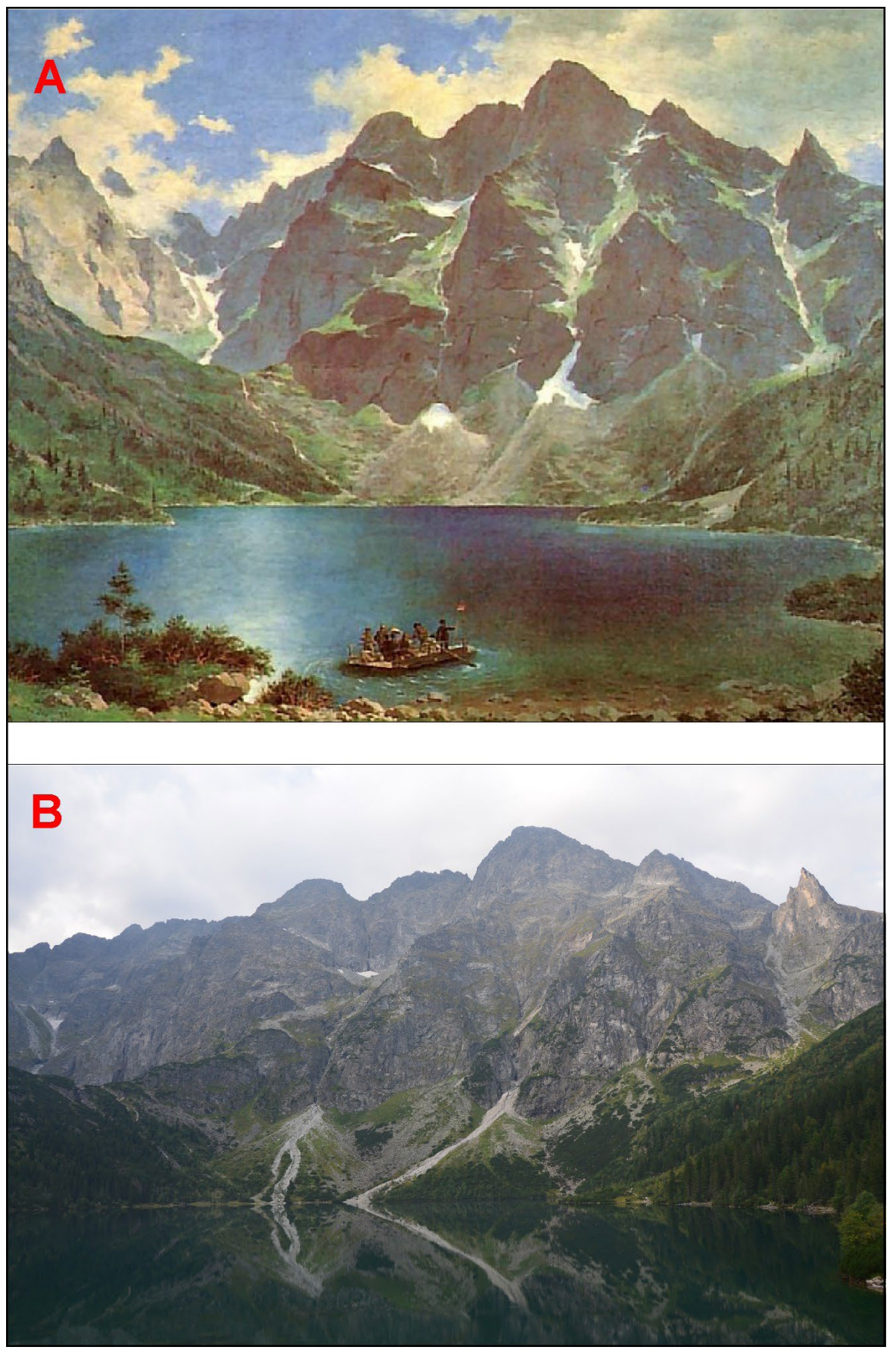

Figure 6. Changes in extent of the dwarf pine shrubs and the montane forest. The Morskie Oko Lake in the Rybi Potok Valley. A: The paint of N. Gtowacki, 1837; B: the present-day view of the area. 


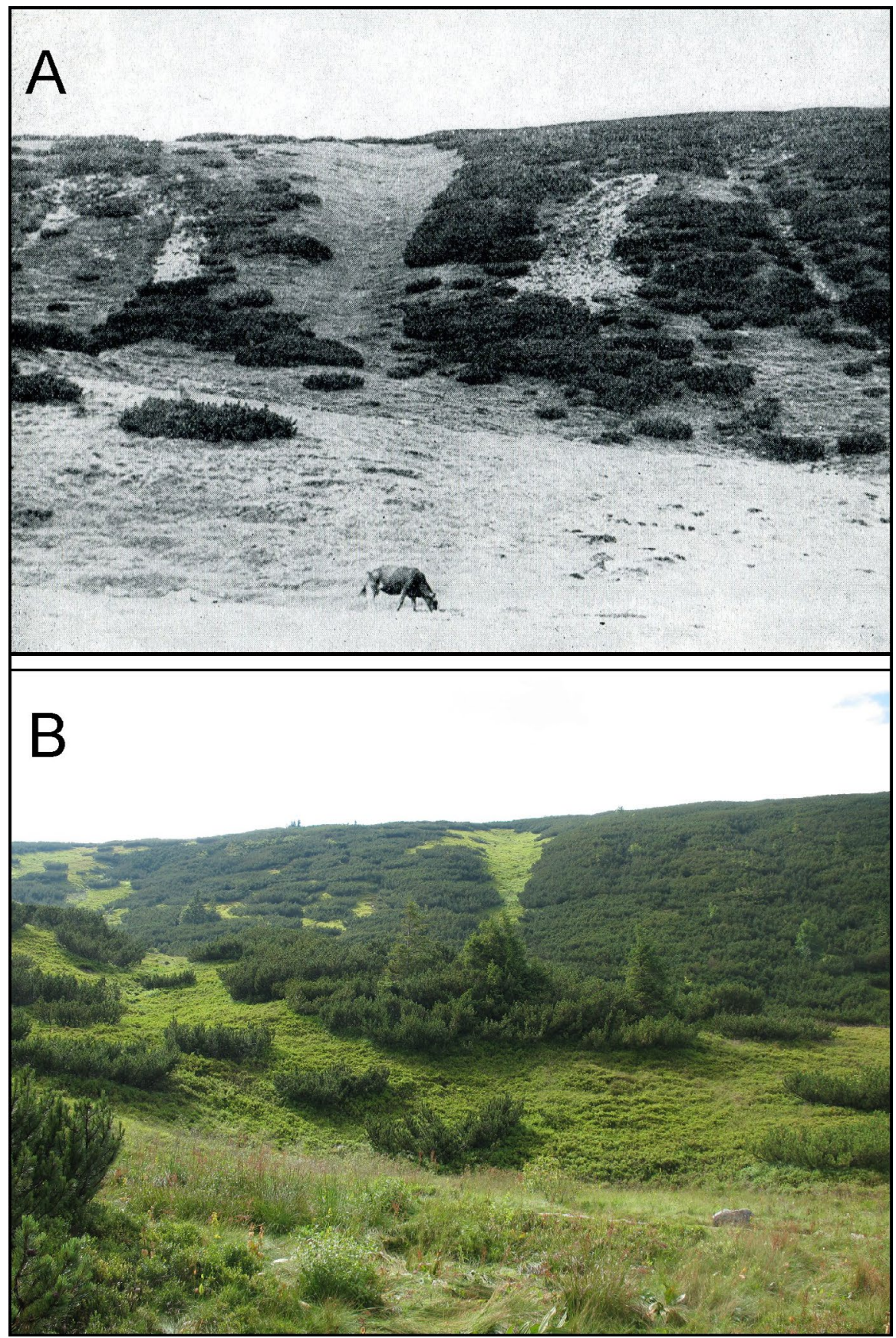

Figure 7. Influence of animals grazing on the extent occupied by dwarf pine shrubs and erosion on the Uhrocie Kasprowe slopes in the Tatras. A: view during intensive grazing; B: the presentday view. 
Along with the grazing, the process of a variety of impacts on the Tatra forests began, including both reducing forest cover and changes in structure of existing forests (Kolowca, 1955; Paryski, 1959; Ciurzycki, 2003). Mid-forest glades, occurring in the forest felling sites, are the second significant effect of pasturage. There were 120 of them in the Polish part of the Tatras when sheep grazing was carried out (Mirek, 1996). Thirty two glades still existed in 1990 within the montane forest zone of the Tatry Reglowe. Twelve of them were used for maintaining the tradition of grazing (so called cultural grazing), and 3 glades were used as hay meadows. The glades differ in area from 1 to 39 ha (Klimek et al., 1990). Dynamics of afforestation of the Tatra glades in TPN was evaluated based on ortophotomaps and satellite images analysis. It was found that the glade area decreased by more than 46\% between 1955 (intensive sheep grazing) and 2004 ( 40 years after cessation of sheep grazing) (Bukowski, 2009). Recent afforestation (Fig. 7) may also be related to climate warming.

Other important effects of grazing, together with the impact of mining, metallurgy, and forest management, are forest communities with distinctly transformed forest stands (Mirek, 1996).

\subsection{Influence of past deforestation on forest structure and slope morphodynamics}

The natural/original forest structure in the Tatra Mountains related to altitudinal climatic zones consists of deciduous forest (with the dominance of beech trees) up to $1200 \mathrm{~m}$ a.s.l., and coniferous forest (with predominating spruce), which reaches the upper timber line at the height of $1550 \mathrm{~m}$ a.s.l (Mirek, 1996). Forests were the element of the natural environment that was most affected by deforestation and fires (Midriak, 1983). Deforestation was mainly caused by activities discussed above and by the development of constructions for which wood was used as the main building material. It resulted in lowering of the upper forest limit and changing a natural structure of the forest into a monoculture (Fabijanowski, 1962; Mirek, 1996). The structure of the deciduous forest zone has been changed, so it is mostly composed of spruce till now (Mirek, 1996; Ciurzycki, 2003).

Indirect, unintentional effects of different human activities in the forest are problems with bark beetles, which appeared since the World War I (Goetel, 1962) and caused dying of trees on a large area in the forest zone of the Tatras. The other indirect effect is facilitating of windthrow on large areas by windstorms of bora type in TANAP or a foehn type in TPN. One of the biggest windthrow of 2.5 milion $\mathrm{m}^{3}$ was on Slovak side of the Tatras in 2004 (Koreń, 2006; Zielonka and Malcher, 2010; Fleicher et al., 2017). Based on the analysis of spatial and temporal distribution of the most catastrophic events, it was found that damages of forest stands by wind and snowfall events are followed by gradations of the bark beetle, and that these phenomena repeat cyclically (Grodzki and Guzik, 2009).

Windthrows result in the specific micro-relief of domes and hollows on the slopes (Kotarba, 1970; Strzyżowski et al., 2016) and influence the sediment flux pattern 
(Kotarba, 1970; Strzyżowski et al., 2018). After the windthrow in 2013 in the Polish Tatra the sediment flux rate for the whole area of TPN is of $3.55 \times 10^{-4} \mathrm{~m}^{3} / \mathrm{m}^{-1} / \mathrm{yr}^{-1}$. The mean sediment flux based on the 48 -year data is $2.76 \times 10^{-5} \mathrm{~m}^{3} / \mathrm{m}^{-1} / \mathrm{yr}^{-1}$ (Strzyżowski et al., 2018).

Both the windthrows and the attacks of bark beetle induced the use of heavy equipment for transporting tree trunks that exerted impacts on existing forest roads and caused formation of new trails of tree trunk transport on slopes. Sheet and linear erosion within roads and trails caused the development of erosional incisions and hollows there, and deepening of the roads' gullies (Rojan, 2010; Fidelus-Orzechowska et al., 2017). Results of a 10-year study showed that 2-3 years after the cessation of intensive use of the forest roads changes in their surface are significantly reduced and the roads became gradually overgrown; sometimes even completely (Rojan, 2015).

\subsection{Influence of grazing on landform and soils transformation}

Intensive grazing of many and numerous sheep herds and cows generate changes in landscape and landforms. Because of that, the continuity of the vegetation cover in the alpine and subalpine zones was broken, and a network of numerous sheep trials was formed (Paryski, 1959). Erosion on the hillslopes resulted in the supply of large amount of material to the valley bottoms by slope wash and debris flows. Examination of the sediments filling the depressions in the glacial cirques and valley bottoms in the Western Tatra demonstrated the human activity on the surrounding slopes since the $14^{\text {th }}-15^{\text {th }}$ centuries (Libelt, 1988; Kaszowski et al., 1988; Kłapyta and Kołaczek, 2009, Kłapyta, 2012). It can be assumed that the degradation of the vegetation cover as a result of animal grazing, enhanced the activity of geomorphic processes related to the deterioration of the climate during the of Little Ice Age. The consequent soil compacting on slopes resulted in the erosional niches and incisions (Fig. 7). About 20 years after the cessation of the intensive animal grazing, a significant reduction of erosion and succession of vegetation onto bare slopes were found (Jahn, 1979). Nevertheless, in the areas used by skiing, these processes were slower, and some erosional landforms are still active (Raczkowska and Kozłowska, 2002, 2010). The grazing influence on landscape is expressed also by presence of the shepherd huts in many places, now kept/protected as historical-heritage objects, yet sometimes serving for other uses. The sheep trials that used to be very dense on the slopes in the past are overgrown now and are not visible, except for those used for hiking.

Animal grazing influenced not only the landform evolution but also soil characteristics as well. The negative impact of grazing had manifested in mechanical deformation of soil cover, disadvantageous changes in air and water properties of the soil, occurrence of various forms of initial and deluvial soils. On the other hand, grazing brought also a positive impact on slopes: due to manuring related to the paddock grazing system the soils were enriched in biogenic components, and plant nutrients were better balanced (Skiba and Zawilińska, 1990). In fifty years since the conversion of pastureland into grasslands and forest, the development of genetic soil horizons occurs in eroded calcareous soils (Wasak and Drewnik, 2015). 


\subsection{Influence of tourism}

Tourism-related human impact is observed along hiking trails, and manifests in gradual anthropogenic erosion (Skawiński, 1993; Krusiec, 1996; Czochański, 2000; Gorczyca and Krzemień, 2002; Rączkowska and Kozłowska, 2010; Fidelus, 2016; Fidelus-Orzechowska et al., 2017). Tourist erosion is generally related to hiking. Results of the hitherto studies indicate that hiking has the most destructive impact on the vegetation and soil covers as well as the intensity of morphogenetic processes (Jodłowski, 2011; Bukowski et al., 2015; Fidelus-Orzechowska et al., 2017). The main erosional effects of hiking are: widening of hiking paths, lowering of their surface and development of erosional micro-forms within them as well as deterioration of compact vegetation cover and introducing synanthropic plant species.

The modification of the relief within hiking paths resulted from the activity of natural morphogenetic processes intensified or induced by the touristic use of the area. The intensity of slope degradation is much higher there than on the slopes not affected by tourism. Midriak (1996) found that soil erosion on the slopes protected with vegetation is $0.01-0.03 \mathrm{~mm}_{\text {year }}{ }^{-1}$, while on the bare surface of hiking paths it increases to $1.7-3.6 \mathrm{~mm}$ year $^{-1}$ in the areas with calcareous substrate. According to 5-year long monitoring of the hiking path at Kasprowy Wierch Mt., which is subjected to a huge tourist traffic (more than 500,000 persons per year) the slope lowering rate is $0.3-1.3 \mathrm{~cm}_{\text {year }}{ }^{-1}$ (Rączkowska and Kozłowska, 2010). A similar slope lowering of $0.89-1.0 \mathrm{~cm}$ year-1 was found in other areas with metamorphic rocks (Fidelus, 2016). Although path degradation indicators are relatively high, it has not led to total loss of the soil cover.

The intensity of modification of the slope paths differs depending on lithology, slope inclination and orientation, soil structure, vegetation cover, seasons and number of tourists (Fidelus-Orzechowska et al., 2017). Widening of hiking paths is spatially differentiated. Their widths range from $<1 \mathrm{~m}$ to $>20 \mathrm{~m}$. Paths less than $1 \mathrm{~m}$ wide account for $83 \%$ of them in TANAP and $47 \%$ in TPN, while those with widths more than $5 \mathrm{~m}$ represent $2 \%$ and $6 \%$, respectively. In the last 15 years, tourist paths have become much wider and deeper along many long stretches in the alpine and subalpine zone. Mean widths were 1-5 $\mathrm{m}$ in 1990, and from 3-5 $\mathrm{m}$ to $10-20 \mathrm{~m}$ in 2012. Maximum widths grew from over $10 \mathrm{~m}$ to over $20 \mathrm{~m}$, respectively (FidelusOrzechowska et al., 2017). Monitoring at the Kasprowy Wierch area showed the path widening only by $2-20 \mathrm{~cm}$ during 5 years, what can be attributed to limiting the path by tape railing introduced by TPN (Racczkowska and Kozłowska, 2010). Both the active morphogenetic processes and touristic use lead to emergence of new landforms of varied origin. Among them there are erosional incisions up to $1 \mathrm{~m}$ deep and wide, nival hollows, deflation hollows and geli-deflation steps (Fig. 8). All tourist trails in the Tatras experience the strongest physical changes during snowmelt in spring, as well as in summer during heavy rainfall events. A distinct asymmetry in the slope transformation within the hiking paths was found in the Western Tatra in the area above the upper timberline. Northern slopes are transformed to a larger degree (Fidelus, 2016; Fidelus-Orzechowska et al., 2017). 


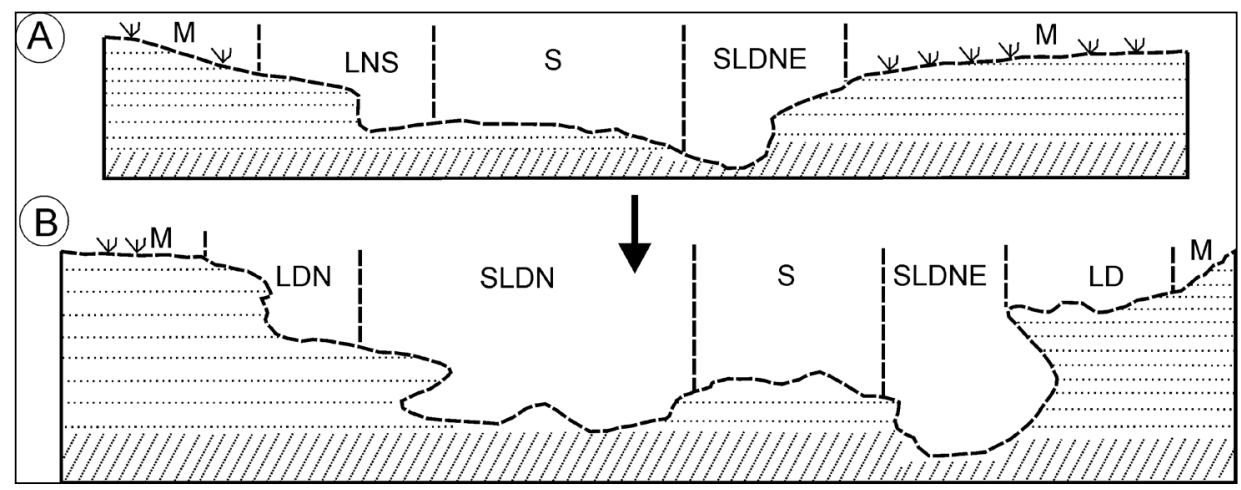

Figure 8. Scheme of long-term changes in the cross-profile of a hiking path (after Fidelus et al., 2017). A: the early stage; B: stage of advanced changes. Explanations of letters: S: slope wash,

E: rill erosion, L: needle ice activity, D: deflation, $N$ : nivation, $M$ : slope stabilized by alpine meadows.

The impact of tourism on the vegetation results in patches of synanthropic vegetation in most of touristic places, e.g. patches of nettle Urtica dioica (Piękoś-Mirkowa 1981; Mirek, 1996; Rączkowska and Kozłowska, 2002, 2010; Kozłowska, 2008). Trampling of the grasslands near hiking paths is also a relevant process related to the hiking. Based on 5-year long monitoring, the rate of widening of the trampled zone is $10 \mathrm{~cm}$ year-1 in the Kasprowy Wierch area. Along the paths, the presence of plant species resistant to trampling was observed, such as Agrostis rupestris or Festuca airoides that form singlespecies patches (Rączkowska and Kozłowska, 2010).

As a result of cave tourism, stalactites and mud caves have been irretrievably destroyed in many places, and large amounts of rubbish have been accumulated both leading to degradation of the natural environment of the caves functioning as unique ecosystems (Siarzewski, 1996).

Climbing mainly affects the vegetation cover and, to a lesser extent, landforms and fauna. Although most climbers climb in summer, the biggest threats to the nature are owing to drytooling on carbonate rocks (Jodłowski, 2015).

Skiing does not produce substantial changes in slope relief due to good management practices in the Polish part of the Tatras (Fidelus-Orzechowska et al., 2017). Only smoothing of coarse boulders by skiers (Skawiński, 1993) and small patches of destroyed alpine swards (Raczkowska and Kozłowska, 2002) were found as evidences of such impacts. However, much greater changes in the vegetation cover and landforms are found in the Slovak part of the Tatras. Destruction of the vegetation cover, erosion over large sectors of the slopes and enlargement of ski routes are observed in skiing areas there.

In the most affected areas by hiking and skiing special actions are undertaken to limit the spatial extent of the tourist traffic and to successfully stop erosion (Fig. 9). These initiatives should lead to development of the vegetation cover that will stabilize the slopes in the short term. 


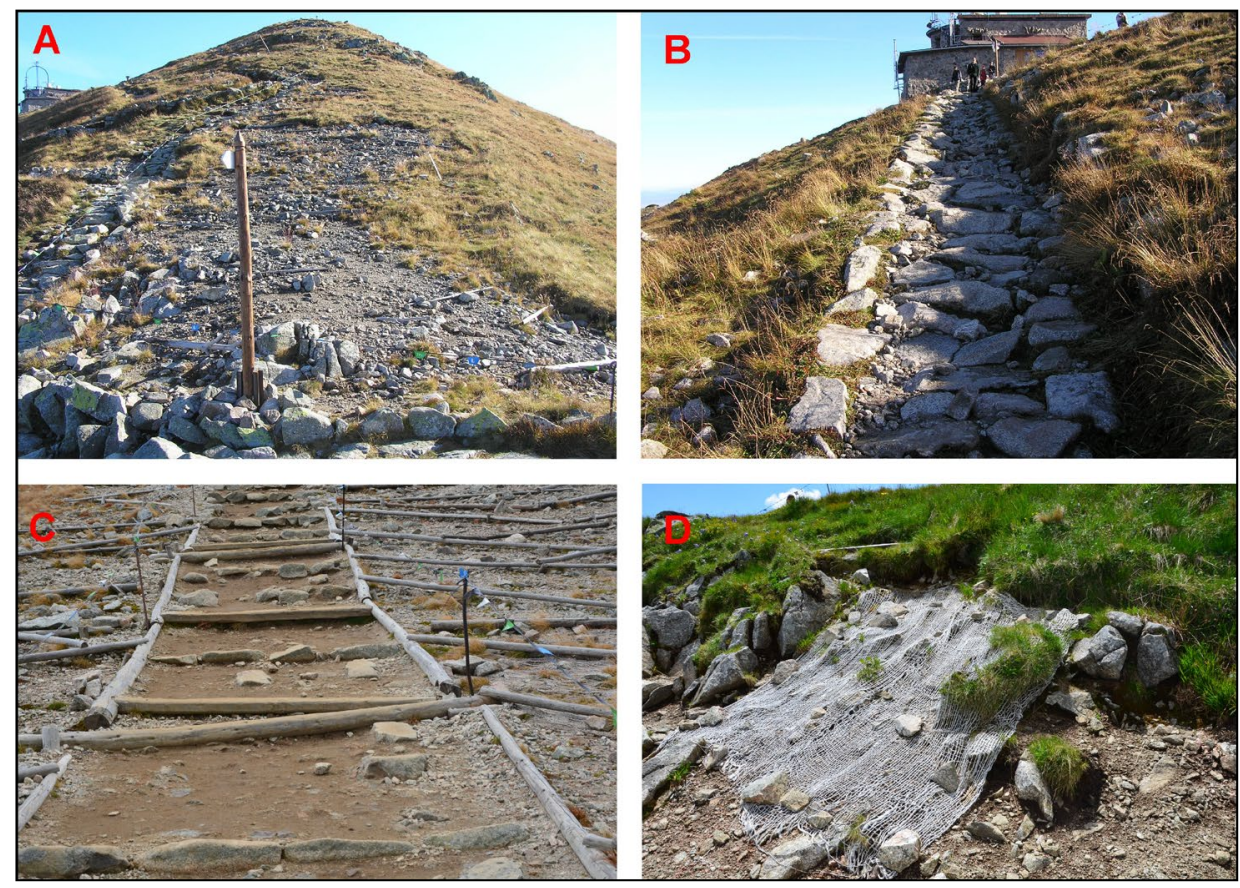

Figure 9. Actions undertaken by TPN to limit the spatial extent of the tourist traffic and to stop tourist erosion. An example from the Kasprowy Wierch Mt. A: Wood beams to stop erosion on the slopes and tape railing limiting the hiking path; B: Hiking path stabilized by boulder pavements; $C$ : Hiking path stabilized by wood beams and limited by wood beams and tape railin; on the adjacent slope destroyed by tourists wood beams and special nets are used to stop erosion and to develop the vegetation cover; D: The successful application of special nets.

Despite the huge tourist traffic, no influence of anthropogenic factors on lake waters was found (Wolanin et al., 2015). Only a limited degradation was observed in the 1990s in the streamflow below mountain huts in the Polish part of the Tatras (Bombówna and Wojtan, 1996). Nowadays stream waters are pure, except at the outlet of the Bystra and Biała Woda streams, where the water has a lower level of purity (Żelazny et al., 2015).

Man-made elements of landscape occur in relation to tourism. On the main ridges of the Tatras there are 2 buildings of meteorological observations and upper stations of cable cars (Lomnický štit Mt., Kasprowy Wierch Mt. - Fig. 4). Mountain huts and hotels, in number of 18, are situated in almost each main valley, also above the forest zone, and few hunting huts are in the forest zone. Chair lifts were constructed in ski areas. In addition, there are power lines, parking areas, asphalt roads, water intakes, sewage treatment plants and hydroelectric power plants. 


\section{Human influence in the Tatras nowadays}

Currently the human activity in the Tatras is generally reduced to the tourism and, at limited degree, to forest economy. Tourist activity involves a huge number of people and covers the whole area of the Tatras. Therefore, tourism should be regarded at present as the main driver of human impact in the Tatras.

The tourism impact is mainly related to hiking. As hiking is allowed only along marked paths, its impact is of linear character, and most of the mountain areas are very slightly affected. Yet, intensive use of the tourist trails causes significant erosional effects on slopes and influences other elements of natural environment, particularly vegetation. The erosive consequences of tourism have been enhanced by forestry works in the Tatras.

In addition, the presence of mountain lodges and cable cars make easier for people to quickly access the core zone of the mountains and their uppermost geocological zones, where nature is more sensitive to long-lasting or irreversible damages. Tourism seems to be currently the greatest threat to both abiotic and biotic elements of natural environment in the Tatras.

It is noteworthy that, as deduced from the text above, the Tatras are particularly different compared with other European mountains, since processes like field abandonment, depopulation, urbanization, which are common in other European mountains, do not affect the Tatras.

\section{Conclusions}

The human impact in the Tatras shows a variety of types, effects, and spatial and temporal organisation.

Regarding chronology, there was a historical, but already non-existent, human impact such as mining, metallurgy, grazing, and deforestation, whereas the contemporary impact is restricted to tourism and forest management.

Landforms and landscape are among the most affected elements of the natural environment: the first due to remnants of historical human activities and effects of present-day erosion by tourism, and the second because of the changes in the altitude and structure of the upper limits of the forest and dwarf pine shrubs as well as large forest areas destroyed by wind or bark beetle.

The impact of tourism, through intensification or triggering of the natural morphogentic processes and the wasting of the compact vegetation cover, and the erosion related to forest economy are regarded as the most significant threats.

From a spatial point of view, the historical human impact until the 1960s-1970s affected the whole area of the Tatras. Currently in the area above the upper forest limit the human influence is either of a linear character, where it occurs along tourist trails, or point-focused if it occurs in downhill skiing areas, and is relatively constant regarding locations. In the forest zone, beside spatially constant linear human influences along the 
tourist trails and roads, there are located sites randomly affected by windthrow and bark beetle attacks.

A tendency to a growing pressure of summer hiking and winter downhill skiing followed by enlarging of the related infrastructure is observed.

\section{Acknowledgements}

The author would like to acknowledge Dr. Teresa Mrozek for improving the English language of this article.

\section{References}

Balon, J., Jodłowski, M., Krąż, P. 2015. The Tatra Mountains physico-geographical regions. Sheet I.4. In: K. Dąbrowska, M. Guzik (Eds.), Atlas Tatr. Przyroda nieożywiona. Zakopane, Tatrzański Park Narodowy, 2 pp.

Barsch, D., Caine, N. 1984. The nature of mountain geomorphology. Mountain Research and Development 4, 287-298.

Balcerkiewicz, S. 1984. Roślinność wysokogórska Doliny Pięciu Stawów Polskich w Tatrach i jej przemiany antropogeniczne. UAM w Poznaniu, Ser. Biologia 25, 1-190.

Batzing, W., Perlik, M., Dekleva, M., 1996. Urbanization and depopulation in the Alps. Mountain Research and Development 16, 335-350.

Baur, B., Cremene, C., Groza, G., Rakosy, L., Schileyko, A.A., Baur, A., Stoll, P., Erhardt, A. 2006. Effects of abandonment of subalpine hay meadows on plant and invertebrate diversity in Transylvania, Romania. Biological Conservation 132, 261-273.

Bebi, P., Seidl, R., Motta, R., Fuhr, M., Firm, D., Krumm, F., Conedera, M., Ginzler, C., Wohlgemuth, T., Kulakowski, D., 2017. Changes of forest cover and disturbance regimes in the mountain forests of the Alps. Forest Ecology Management 15, 43-56. https://doi. org/10.1016/j.foreco.2016.10.028.

Beniston, M., 2000. Environmental changes in mountains and uplands. Arnold, London, 172 pp.

Boltižiar, M. 2007. Štruktúra vysokohorskej krajiny Tatier. Univerzita Konštatnina Filozofa v Nitre, $247 \mathrm{pp}$.

Bombówna, M., Wojtan, K. 1996. Zmiany składu chemicznego wody jezior tatrzańskich na przestrzeni lat. In: Z. Krzan (Ed.), Przyroda Tatrzańskiego Parku Narodowego a Człowiek. Vol. 3. Wpływ człowieka. Tatrzański Park Narodowy, Polskie Towarzystwo Przyjaciół Nauk o Ziemi, Zakopane, pp. 56-60.

Bukowski, M. 2009. Dynamika zarastania polan tatrzańskich. In: M. Guzik (Ed.), Dtugookresowe zmiany w przyrodzie i użytkowaniu TPN. Wydawnictwa Tatrzańskiego Parku Narodowego, Zakopane, pp. 15-32.

Bukowski, M., Fidelus, J., Gorczyca, E., Krzemień, K. 2015. Długookresowe przekształcenia rzeźby na stokach na wybranych odcinkach ścieżek turystycznych w Tatrach Zachodnich. In: A. Chrobak, A. Kotarba (Eds.), Nauka Tatrom. Vol. 1. Nauki o Ziemi. Wydawnictwa Tatrzańskiego Parku Narodowego, Zakopane, pp. 45-50.

Chaloupecký, V. 1957. Valaši na Slovensku. Praha, Orbis, 117 pp.

Chmiel, J. 1996. Kulturowy wypas owiec i krów w Tatrzańskim Parku Narodowym. In: Z. Krzan (Ed.), Przyroda Tatrzańskiego Parku Narodowego a Człowiek. T. 3. Wpływ Człowieka. Tatrzański Park Narodowy, Polskie Towarzystwo Przyjaciół Nauk o Ziemi, Zakopane, pp. 86-89.

Ciurzycki, W. 2003. Gospodarka pasterska a lasy Tatr Polskich. Sylwan 11, 80-85. 
Coulthard, T.J., Macklin, M.G. 2001. How sensitive are river systems to climate and land use changes? A model based evaluation. Journal of Quaternary Science 16, 347-351.

Czochański, J.T. 2000. Wpływ użytkowania turystycznego na rozwój procesów i form erozyjnodenudacyjnych w otoczeniu szlaków. In: D. Borowiak, J.T. Czochański (Eds.), Z badań geograficznych w Tatrach Polskich. Wydawnictwo Uniwersytetu Gdańskiego, Gdańsk, pp. 331-343.

Czubernat, S., Marchlewski, A. 2005. Turystyka w wysokogórskim środowisku Tatr Polskich. In: Z. Ładygin, B. Chovancová (Eds.), Monitoring ruchu turystycznego w Tatrach. Wydawnictwo Tatrzańskiego Parku Narodowego, Zakopane, pp. 43-48.

Dziewolski, J., Skawiński, P. 1988. Zmiany w składzie gatunkowym i strukturze wiekowej wybranych drzewostanów Tatrzańskiego Parku Narodowego. Ochrona Przyrody 49, 75-90.

Fabijanowski, J. 1962. Lasy tatrzańskie. In: J. Szafer (Ed.), Tatrzański Park Narodowy. Wyd. II. Zakład Ochrony Przyrody PAN, Kraków, pp. 240-304.

Fabijanowski, J.,Dziewolski,J. 1996. Gospodarka leśna. In:Z. Mirek (Ed.), Przyroda Tatrzańskiego Parku Narodowego. Tatrzański Park Narodowy, Kraków-Zakopane, pp. 675-696.

Fidelus, J. 2016. Slope transformations within tourist footpaths in the northern and southern parts of the Western Tatra Mountains (Poland, Slovakia). Zeitschrift für Geomorphologie 60 (3), 139-162.

Fidelus-Orzechowska, J., Gorczyca, E., Krzemień, K. 2017. Geomorfologiczne skutki gospodarki turystycznej w Tatrach, Tatrzański Park Narodowy, Instytut Geografii i Gospodarki Przestrzennej UJ, Kraków, 239 pp.

Fleischer, P., Pichler, V., Fleischer, P. Jr., Holko, L., Máliš, F., Gömöryová, E., Cudlín, P., Holeksa, J., Michalová, M., Homolog, Z., Karenina, J., Střelcová, K., Hlavá, P. 2017. Forest ecosystem services affected by natural disturbances, climate and land-use changes in the Tatra Mountains. Climate Research 73, 57-71, https://doi.org/10.3354/cr01461.

Galop, D., Jalut, G., 1994. Differential human impact and vegetation history in two adjacent Pyrenean valleys in the Ariège basin, southern France, from 3000 BP to the present. Vegetation History and Archaeobotany 3, 225-244.

Galop, D., Rius, D., Cugny, C., Mazier, F., 2013. A history of long-term human-environment interactions in the French Pyrenees inferred from the pollen data. In: L.R. Lozny (Ed.), Continuity and Change in Cultural Adaptation to Mountain Environments, Studies in Human Ecology and Adaptation 7. Springer, New York, pp. 19-30. Doi: 10.1007/978-1-4614-57022_3.

García-Ruiz, J.M., Valero-Garcés, B.L. 1998. Historical geomorphic processes and human activities in the Central Spanish Pyrenees. Mountain Research and Development 18, 309320.

Gašpar, M. 2002. Tatry - staré pohladnice rozprávujú. Poprad, Region, 263 pp.

Gądek, B., Grabiec, M., Kędzia, S., Rączkowska, Z. 2016. Reflection of climate changes in the structure and morphodynamics of talus slopes (the Tatra Mountains Poland). Geomorphology 263, 39-49. https://doi.org/10.1016/j.geomorph.2016.03.024.

Gądek, B., Kaczka, R.J., Rączkowska, Z., Rojan, E., Casteller, A., Bebi, P. 2017. Snow avalanche activity in Żleb Żandarmerii in a time of climate change (Tatra Mts., Poland). Catena 158, 201-212, https://doi.org/10.1016/j.catena.2017.07.005.

Goetel, W. 1962. Dzieje realizacji Tatrzańskiego Parku Narodowego. In: W. Szafer (Ed.), Tatrzański Park Narodowy. PAN, Kraków, pp. 592-626.

Gorczyca, E., Krzemień, K. 2002. Wpływ ruchu turystycznego na rzeźbę Tatrzańskiego Parku Narodowego. In: W. Borowiec, A. Kotarba, A. Kownacki, Z. Krzan, Z. Mirek (Eds.), Przemiany środowiska przyrodniczego Tatr. Tatrzański Park Narodowy, PTPNoZ, Oddz. w Krakowie, Kraków-Zakopane, pp. 389-393. 
Grodzki, W., Guzik, M. 2009. Wiatro- i śniegołomy oraz gradacje kornika drukarza w Tatrzańskim Parku Narodowym na przestrzeni ostatnich 100 lat. Próba charakterystyki przestrzennej. In: M. Guzik (Ed.), Dtugookresowe zmiany w przyrodzie i użytkowaniu TPN. Wydawnictwa Tatrzańskiego Parku Narodowego, Zakopane, pp. 33-46.

Guzik, M. 2008. Analiza wptywu czynników naturalnych i antropogenicznych na kształtowanie się zasięu lasu i kosodrzewiny w Tatrach. PhD Thesis. Uniwersytet Rolniczy im. Hugona Kołłątaja, Wydział Leśny, Kraków, 172 pp.

Harvan, L. 1965. Ako sa vyriešila pastva w TANAP. Zbornik prác TANAP 8, pp. 231-253.

Häufler, V. 1955. Horské oblasti v Československu a ich využiti. Praha, CSAV, 675 pp.

Holub-Pacewiczowa, Z. 1931. Osadnictwo pasterskie i wędrowne w Tatrach i na Podtatrzu. Prace Komisji Geograficznej PAU 1, Kraków, 508 pp.

Jahn, A. 1979. On Holocene and present-day morphogenetic processes in the Tatra Mountains. Studia Geomorphologica Carpatho-Balcanica 13, 111-129.

Janoška, M. 1923. Sprievodca po Tatrách. Liptovský Mikláš, F. Klimeš, 498 pp.

Jodłowski, M. 2010. Górna granica zarośli subalpejskich w wybranych pasmach górskich Europy Środkowej-uwarunkowania i typy ekotonu. Czasopismo Geograficzne 1-2, 43-60.

Jodłowski, M. 2011. Zasady dobrej praktyki w zarzadzaniu ruchem wspinaczkowym na obszarach chronionych. Wydawnictwo IGiGP UJ, Kraków, 208 pp.

Jodłowski, M. 2015. Nowa koncepcja zarządzania ruchem wspinaczkowym w Tatrzańskim Parku Narodowym jako forma ograniczenia wpłwyu taternictwa na środowisko. In: A. Chrobak, T. Zwijacz-Kozica (Eds.), Nauka Tatrom. Vol. 3. Człowiek i środowisko. Wydawnictwo Tatrzańskiego Parku Narodowego, Zakopane, pp. 63-72.

Jost, H. 1962. O górnictwie i hutnictwie w Tatrach Polskich. Wydawnictwa Naukowo-Techniczne, Warszawa, $183 \mathrm{pp}$.

Jost, H. 1991. Górnictwo, hutnictwo i inne rodzaje przemysłu na terenie Zakopanego i okolic. In: R. Dutkowa (Ed.), Zakopane - czterysta lat dziejów. Krajowa Agencja Wydawnicza, Kraków, pp. 363-389.

Jost, H., Paulo A. 1985, Złoża, dawne górnictwo i przemysł. Mapa 29. In: K. Trafas (Ed.), Atlas Tatrzańskiego Parku Narodowego. Wojskowe Zakłady Kartograficzne, Zakopane-Kraków, p. 29.

Kaszowski, L., Krzemień, K., Libelt, P. 1988. Postglacjalne modelowanie cyrków lodowcowych w Tatrach Zachodnich. Zeszyty Naukowe UJ, Prace Geograficzne 71, 121-141.

Kędzia, S., Kotarba, A. 2018. The Little Ice Age in the Tatra Mountains Cuadernos de Investigación Geográfica 44 (1), 47-67, http://doi.org/10.18172/cig.3350.

Klimaszewski, M. 1988. Rzeźba Tatr Polskich. PWN. Warszawa, 709 pp.

Klimek, K., Łajczak, A., Skiba, S. 1990. Charakterystyka abiotycznego środowiska polan reglowych polskich Tatr. In: Wypas owiec a zachowanie biocenoz polan reglowych $\mathrm{w}$ Tatrach. Studia Naturae ser. A 34, 11-38.

Kłapyta,P., 2012. Ewolucja rzeźby wysokogórskiej Tatr Zachodnich w późnym glacjale i holocenie. Uniwersytet Jagielloński, Kraków, 253 pp.

Kłapyta, P., Kołaczek, P. 2009. The last millenium slope processes and anthropogenic activity recorded in the sediments from the Pyszniańska glade, Western Tatra Mountains (Poland). Studia Geomorphologica Carpatho-Balcanica 43, 145-163

Kolowca, J. 1955. Pasterstwo w Tatrzańskim Parku Narodowym. In: W. Szafer (Ed.), Tatrzański Park Narodowy. Zakład Ochrony Przyrody PAN, Kraków, pp. 245-256.

Kotarba, A. 1970. The morphogenetic role of foehn wind in the Tatra Mts. Studia Geomorphologica Carpatho-Balcanica 4, 171-188.

Kotarba, A. 2004. Zdarzenia geomorfologiczne w Tatrach Wysokich podczas małej epoki lodowej. Prace Geograficzne IG i PZ PAN 197, 9-55. 
Koreň, M. 2006. Vetrova kalamita 19. novembra 2004: nove pohl'ady a konsekvencie. Tatry 44, 7-28.

Kozłowska, A. 2008. Strefy przejścia między układami roślinnymi - analiza wielkoskalowa na przykładzie roślinności górskiej. Prace Geograficzne IG i PZ PAN 215, 152 pp.

Krusiec, M. 1996. Wpływ ruchu turystycznego na przekształcanie rzeźby Tatr Zachodnich na przykładzie Doliny Chochołowskiej. Czasopismo Geograficzne 67, 303-320.

Lasanta, T., Arnáez, J., Pascual, N., Ruiz-Flaño, P., Errea, M.P., Lana-Renault, N. 2017. Spacetime process and drivers of land abandonment in Europe. Catena 149, 810-823. https://doi. org/10.1016/j.catena.2016.02.024.

Latocha, A. 2009. Land-use changes and longer-term human-environment interactions in a mountain region (Sudetes Mountains, Poland). Geomorphology 108, 48-57. https://doi. org/10.1016/j.geomorph.2008.02.019.

Leonelli, G., Pelfini, M., Morra di Cella, U. 2009. Detecting climatic treeline in the Italian Alps. The Influence of Geomorphological Factors and Human Impacts. Journal of Physical Geography 30, 4, 338-352.

Libelt, P. 1988. Warunki i przebieg sedymentacji osadów postglacjalnych w cyrkach lodowcowych Tatr Zachodnich na przykładzie kotła Starorobociańskiego. Studia Geomorphologica Carpatho-Balcanica 22, 63-81.

Liberak, A.M. 1927. Górnictwo i hutnictwo w Tatrach Polskich. Wierchy 5, 13-30.

Lukniš, M. 1973. Reliéf Vysokých Tatier a ich predpolia. Bratislava, Vyd. SAV, 375 pp.

Mac Donald, D., Crabtree, J.R., Wiesingers, G., Dax, T., Starnou, N., Fleury, P., Gutierrez Lazpita, J., Gibon, A., 2000. Agricultural abandonment in mountain areas of Europe: environmental consequences and policy response. Journal of Environmental Managament 59, 47-69.

Midriak, R. 1972. Deštrukcia pôdy vo vysokohorskiej oblsti Belanských Tatier. Lesnícke štúdie 11-12, Bratislava, Priroda, 207 pp.

Midriak, R. 1983. Morfogenéza povrchu vysokých pohori. Bratislava, VEDA, 516 pp.

Midriak, R. 1996. Present-day procesess and micro-landforms evaluation: case of Kopske Sedlo, the Tatra Mountains, Slovakia. Studia Geomorphologica Carpatho-Balcanica 30, 39-50.

Mirek, Z. 1996. Antropogeniczne zagrożenia i przekształcenia środowiska przyrodniczego. In: Z. Mirek (Ed), Przyroda Tatrzańskiego Parku Narodowego. Tatrzański Park Narodowy, Kraków-Zakopane, pp. 595-617.

Myczkowski, S., Skawiński, P., Lesiński J. 1985. Synantropizacja lasów. In: K. Trafas (Ed.), Atlas Tatrzańskiego Parku Narodowego. Wojskowe Zakłady Kartograficzne, Zakopane-Kraków, p. 21.

Paryski, W. 1959. Szlaki pasterskie w Tatrach i na Podtatrzu. In: W. Antoniewicz (Ed.), Pasterstwo Tatr Polskich i Podhala. Vol. 1. Fizjografia i geografia pasterstwa Tatr Polskich Podhala. Wydawnictwo PAN, Zakład im. Ossolińskich, Wrocław-Warszawa-Kraków.

Piękoś-Mirkowa, H. 1981. Antropogeniczne przekształcenia szaty roślinnej w Tatrzańskim Parku Narodowym. In: Z. Wójcik (Ed.), Ochrona Tatr w Polsce Ludowej. Wyd. PTPNoZ i TPN, Warszawa, pp. 259-286.

Piękoś-Mirkowa, H. 1986. Aktualne problem ochrony zasobów genowych roślin naczyniowych w Tatrzańskim Parku Narodowym. Acta Univesitas Lodziensis, Folia Sozologica 3, 143-159.

Piękoś-Mirkowa, H., Mirek, Z. 1996. Zbiorowiska roślinne. In: Z. Mirek (Ed.), Przyroda Tatrzańskiego Parku Narodowego. Tatrzański Park Narodowy, Kraków-Zakopane, 237-274.

Piotrowska, K., Danel, W., Iwanov, A., Gaździcka, E., Rączkowski, W., Bezák, V., Magla, J., Polák, M., Kohút, M., Gross, P. 2015. Plate IV.1. Geology. Map 1. 1 : 100 000. In: K. Dąbrowska, M. Guzik (Eds.), Atlas Tatr. Przyroda nieożywiona. Zakopane, Tatrzański Park Narodowy, 2 pp. 
Plesník, P. 1971. Horná hranica lesa vo Vysokých a Belanských Tatrách. Bratislava, Vydatelstvo SAV, 240 pp.

Plesník, P. 1973. La Limite Supérieure de la Forêt dans les Hautes Tatras. Arctic and Alpine Research 5, 37-44.

Podolák, J. 1967. Pastierstvo v oblasti Vysokých Tatier. Bratislava, Vydatelstvo SAV, 212 pp.

Py, V., Véron, A., Edouard, J-C, de Beaulieu, J-L., Ancel, B., Segard, M., Durand, A., Leveau, P. 2014. Interdisciplinary characterisation and environmental imprints of mining and forestry in the upper Durance valley (France) during the Holocene. Quaternary International 353, 74-97.

Radwańska-Paryska, Z. 1959. Ochrona przyrody a pasterstwo. In: W. Antoniewicz (Ed.), Pasterstwo Tatr Polskich i Podhala. Vol. 1. Fizjografia i geografia pasterstwa Tatr Polskich Podhala. Wydawnictwo PAN, Zakład im. Ossolińskich, Wrocław-Warszawa-Kraków, pp. 175-191.

Radwańska-Paryska, Z. 1963. Roślinność synantropijna we florze Tatr. In: W. Antoniewicz (Ed.) Pasterstwo Tatr Polskich i Podhala. Vol. 5. Wędrówki pasterskie i nazewnictwo ludowe Tatr Polskich i Podhala. Zakład Narodowy im. Ossolińskich, PAN, Wrocław, pp. 233-254.

Radwańska-Paryska, Z., Paryski, W. 1995. Wielka Encyklopedia Tatrzańska. Wydawnictwo Górskie. Poronin, 1555 pp.

Rączkowska, Z., Kozłowska, A.B. 2002. Odzwierciedlenie wpływów antropogenicznych w wybranych elementach środowiska przyrodniczego otoczenia Kasprowego Wierchu. In: W. Borowiec, A. Kotarba, A. Kownacki, Z. Krzan, Z. Mirek (Eds.), Przemiany środowiska przyrodniczego Tatr. Wydawnictwo Instytutu Botaniki PAN, Kraków-Zakopane, pp. 403-406.

Rączkowska, Z., Kozłowska, A. 2010. Wpływ turystyki na rzeźbę i roślinność przy ścieżkach w otoczeniu Kasprowego Wierchu. In: Z. Krzan (Ed.), Nauka a Zarzadzanie obszarem Tatr $i$ ich otoczeniem. Vol. 3. Człowiek i środowisko. Tatrzański Park Narodowy, Zakopane, pp. 21-28.

Rączkowski, W., Boltižiar, M., Rączkowska, Z. 2015. Plate V.1. Relief. Map 1. Relief 1 : 100000. In: K. Dąbrowska, M. Guzik (Eds.), Atlas Tatr. Przyroda nieożywiona. Tatrzański Park Narodowy, Zakopane, 2 pp.

Rixen, Ch., Rolando, A., Ed. 2013. The Impacts of Skiing and Related Winter Recreational Activities on Mountain Environments. Bentham EBooks, 221 pp. https://doi.org/10.2174/9 7816080548861130101.

Rojan, E. 2010. The role of severe windstorms in modifying the mountain forest floor relief; A case of the blowdown area in the Slovakian High Tatras. Czasopismo Geograficzne 81, 103-123.

Rojan, E. 2015. Changes in unpaved forest roads of the windthrow area in the Slovak High Tatra Mts in years 2004-14. Štúdie o Tatranskom Národnom Parku 11 (44), 97-106.

Schwörer, C., Henne, P.D., Tinner, W., 2014. A model-data comparison of Holocene timberline changes in the Swiss Alps reveals past and future drivers of mountain forest dynamics. Global Change Biology 20, 1512-1526.

Siarzewski, W. 1996. Degradacja środowiska przyrodniczego jaskiń tatrzańskich. In: Z. Krzan (Ed.), Przyroda Tatrzańskiego Parku Narodowego a Człowiek. Vol. 3. Wpływ człowieka. Tatrzański Park Narodowy, Polskie Towarzystwo Przyjaciół Nauk o Ziemi, Zakopane, pp. 48-50.

Skawiński, P. 1993. Oddziaływanie człowieka na przyrodę kopuły Kasprowego Wierchu oraz Doliny Goryczkowej w Tatrach. In: W. Cichocki (Ed.), Ochrona Tatr w obliczu zagrożeń. Wyd. Muzeum Tatrzańskiego, pp. 197-226.

Skawiński, P., Krzan, Z. 1996. Narciarstwo. In: Z. Mirek (Ed.), Przyroda Tatrzańskiego Parku Narodowego. Tatrzański Park Narodowy, Kraków-Zakopane, pp. 697-714. 
Skiba, S., Zawilińska, L. 1990. Soils of grazed glades in the Tatras. Studia Naturae ser. A 34, 39-49. Slaymaker, O., Embleton-Hamann, Ch. 2009. Mountains. In: O. Slaymaker, T. Spencer, Ch. Embleton-Hamann (Eds.), Geomorphology and Global Environmental Change. Cambridge University Press, Cambridge, pp. 37-70.

Sokołowski, M. 1928. O górnej granicy lasu w Tatrach. Kraków, 188 pp.

Strzyżowski, D., Fidelus, J., Żelazny, M. 2016. Geomorphological changes within a hillslope caused by a windthrow event in the Tatra Mountains, Southern Poland. Geografiska Annaler: Series A, Physical Geography 98 (4) 347-360.

Strzyżowski, D., Fidelus, J., Żelazny, M. 2018. Sediment transport by uprooting in the forested part of the Tatra Mountains, southern Poland. Catena 160, 329-338.

Szafarski, J. 1972. Poznanie Tatr. Wydawnictwo „Sport i Turystyka”, Warszawa, 619 pp.

Śmiałowska, Z. 1962, Aktualne zagadnienia pasterstwa w TPN. In: W. Szafer (Ed.), Tatrzański Park Narodowy. PAN, Kraków, pp. 559-578.

Šturcel, M. 2006. Monitoring návštevnosti TANAPu 5-7.8.2004. In: Tatrzański Park Narodowy na tle innych górskich terenów chronionych. Vol. 3. Z. Krzan (Ed.), Człowiek i Środowisko. Tatrzański Park Narodowy, Polskie Towarzystwo Przyjaciół Nauk o Ziemi, Zakopane, pp. 109-115.

Švajda, J., Šturcel, M. 2005. Turystyka w wysokogórskim środowisku Tatr Słowackich. In: Z. Ładygin, B. Chovancová (Eds.), Monitoring ruchu turystycznego w Tatrach. Wydawnictwo Tatrzańskiego Parku Narodowego, Zakopane, pp. 37-41.

Tucker, G.E., Slingerland, R.L. 1994. Erosional dynamics, flexural isostasy and long-lived escarpments: a numerical modelling study. Journal of Geophysical Research 99, 229-243.

Ustrnul, Z., Walawender, E., Czekierda, D., Št’astný, P., Lapin, M., Mikulová, K. 2015. Precipitation and snow cover. Plate II.3. Maps 1 and 5 (1: 250 000). In: K. Dąbrowska, M. Guzik (eds.), Atlas Tatr. Przyroda nieożywiona. Zakopane, Tatrzański Park Narodowy, 2 pp.

Valsecchi, V., Carraro, G., Conedera, M., Tinner, W. 2010. Late-Holocene vegetation and landuse dynamics in the southern Alps (Switzerland) as a basis for nature protection and forest management. The Holocene 20 (4), 483-495.

Vandenberghe, J. 2002. The relation between climate and river processes, landforms and deposits during the Quaternary. Quaternary International 91, 17-23.

Wasak, K., Drewnik, M. 2015. Land use effects on soil organic carbon sequestration in calcareous Leptosols in former pastureland - a case study from the Tatra Mountains (Poland). Solid Earth 6 (4), 1103-1115.

Wolanin, A., Chmielewska-Błotnicka, D., Jelonkiewicz, Ł., Żelazny, M. 2015. Spatial variation of the chemical composition of lake waters in the Tatra National Park. Limnological Review 15 (3), 119-127. https://doi.org/10.2478/limre-2015-0013.

Zielonka, T., Malcher, P. 2010. The dynamics of a mountain mixed forest under wind disturbances in the Tatra Mountains, central Europe - a dendroecological reconstruction. Canadian Journal of Forest Research 39, 2215-2223.

Zwoliński, S. 1984. Wpływ hut zakopiańskich na lasy tatrzańskie. Parki Narodowe i Rezerwaty Przyrody 5, 1, 43-50.

Żelazny, M., Siwek, J., Liová, S., Šimor, V., Dąbrowska, K., Wolanin, A., Pociask-Karteczka, J., Pęksa, Ł., Gajda, A., Siwek, J.P., Rzońca, B., Gavurník, J. 2015. Hydrological conditions. Plate III.1. In: K. Dąbrowska, M. Guzik (Eds.), Atlas Tatr. Przyroda nieożywiona. Zakopane, Tatrzański Park Narodowy, 2 pp.

Żmudzka, E., Nejedlik, P., Mikulova, K. 2015. Temperature, thermal indices. Plate II.2. In: K. Dąbrowska, M. Guzik (Eds.), Atlas Tatr. Przyroda nieożywiona. Zakopane, Tatrzański Park Narodowy, 2 pp. 